\title{
Upper extremity deep venous thrombosis and stenosis after implantation of pacemakers and defibrillators; A prospective study
}

\author{
MORTEZA SAFI ${ }^{1,2}$, MOHAMMAD ALI AKBARZADEH $^{1,2}$, AZADEH AZINFAR $^{1,2}$, \\ MOHAMMAD HASAN NAMAZI ${ }^{1,2}$, ISA KHAHESHI ${ }^{1,2}$ \\ ${ }^{1}$ Cardiovascular Research Center, Shahid Beheshti University of Medical Sciences, Tehran, Iran \\ ${ }^{2}$ Cardiology Department, Shahid Modarress Hospital, Tehran, Iran
}

\begin{abstract}
Background. Obstruction of the access vein following cardiac pacemaker and defibrillator implantation is a common complication. However, the exact incidence and contributing risk factors are unknown. The aim of this study is to determine the incidence and analyze the contribution of each risk factor.

Methods. 57 consecutive patients candidate for their first transvenous pacemaker, implantable cardioverter-defibrillator (ICD), or cardiac resynchronization therapy device implantation were enrolled. After implantation, venography of the ipsilateral peripheral arm was performed. Patients underwent their second venography after the follow-up period of 3 to 6 months.

Results. 42 patients $(13$ females, mean age $59.71 \pm 12.33$ ) completed the study. The followup venography showed significant venous obstruction (more than 50\%) in $9(21 \%)$ patients, but in none of the individuals, venography revealed total occlusion of the veins. Patients with obstruction had more leads in their veins $(2.56 \pm 0.53$ vs $1.58 \pm 0.71, \mathrm{P}=0.001)$. Venous obstruction was significantly more prevalent in patients with implanted cardiac resynchronization therapy device compared with an ICD or pacemaker $(p=0.01)$. Age, gender, diabetes mellitus, hypertension, ischemic heart disease and antiplatelet consumption did not reveal any other contribution to the risk of thrombosis. In multivariate analysis, total lead number was a positive predictor for venous occlusion ( $\mathrm{P}=0.015$, OR:19.2, and CI: 1.7-207.1).

Conclusion. Venous obstruction is relatively frequent after pacemaker or ICD implantation. This study also shows that pacemaker and ICD leads have a similar risk for lead-related venous obstruction. However, patients with multiple leads are associated with an increased risk.
\end{abstract}

Key words: Complications; Venous obstruction; Risk factors; Pacemaker; Implantable cardioverter-defibrillator.

\section{INTRODUCTION}

Obstruction of the access vein is a common and well-known complication following cardiac pacemaker and defibrillator implantation [1, 2]. Although the clinical symptom is rare, it can make the follow-up procedures such as system revision and lead extraction or upgrade difficult or even impossible [2,3]. This complication was mostly evaluated at the time of generator replacement as a late complication, but in a few studies, it has been shown that it can occur very soon (in the first three months) after implantation, and its incidence is not really low in the first few months [4-6].

One the other hand, the risk factors for the development of device-associated venous obstruction have not been clearly determined till now [7]. Such data can provide insight into thrombotic risks among patients prior to implantation and may be used to guide prophylactic strategies in high risk patients.

\section{MATERIALS AND METHODS}

This prospective observational study was performed at the Department of Cardiology of Modarress Hospital, Tehran, Iran. The study protocol was approved by the institutional ethic committee of cardiovascular research center of Shahid Beheshti University of Medical Sciences. Written informed consent was obtained from all participants prior to the device implant.

Between November 2015 and April 2015, consecutive patients above 18 years of age who were admitted to our institution for their first transvenous implant of pacemaker, implantable cardioverter-defibrillator (ICD), or cardiac resyn- 
chronization therapy (CRT) device were considered eligible for the study. Patients with a history of previous venous thromboembolism, coagulation disturbances, malignancy, treated with anticoagulant or with a high serum creatinine (more than $1.5 \mathrm{mg} / \mathrm{dL}$ ) were excluded.

The lead insertions were performed by transvenous access after subclavian vein puncture in the catheterization laboratory using standard implantation techniques. Type of device was chosen by the attending physician, according to the patient's presentation and the ACC/AHA Guidelines [8].

At the end of the procedure, $20 \mathrm{~mL}$ of contrast medium were injected through the ipsilateral peripheral arm vein in all participating patients and contrast media flow through the upper extremity and subclavian vein were recorded by cineangiography in the anteroposterior view to detect upper limb venous stenosis or occlusion and also to have the baseline anatomy of these veins. Patients with abnormal findings or baseline stenosis were excluded from the study.

All patients underwent a routine venography of the same arm between the $3^{\text {rd }}$ to $6^{\text {th }}$ month after implantation with the same protocol as the baseline. All the cineangiograms were recorded.

Baseline and follow-up venograms of each patient were reviewed by two electrophysiologists and the findings were graded as either completely obstructed (clear interruption of contrast flow), partially obstructed (more than 50\% compared with baseline venogram) or not obstructed (less than $50 \%$ compared with baseline venogram).

\section{STATISTICAL ANALYSIS}

Continuous data are expressed as mean $\pm \mathrm{SD}$, and the categorical variables as percentages. Data analysis was performed by using SPSS statistical software (version 19.0, SPSS Inc., Chicago, IL, USA). Normal distribution was checked by ShapiroWilk test. Continuous variables were compared by Student's t-test in case of normal distribution. Otherwise, the non-parametric Mann-Whitney U test was used. Categorical variables were compared using the chi-square test and the Fisher exact test for cell count less than five. To estimate odds ratios and $95 \%$ confidence intervals of the risk factors, we included all the parameters that showed a $\mathrm{P}$ value less than 0.5 during bi-variable correlation into our binary logistic regression analysis model. A $\mathrm{P}$ value which equals to or less than 0.05 was considered statistically significant.

\section{RESULTS}

During the study period, 79 consecutive patients were considered for enrollment. Venography was performed in 57 patients who gave written informed consent at the time of implantation. 4 patients died before the control venography, 4 patients were excluded from the study since they met one of the exclusion criteria (rise of serum creatinine more than 1.5 or starting anticoagulants due to atrial fibrillation), 1 patient had baseline venous occlusion of more than $50 \%$ and 6 patients were lost to follow-up. All the remained 42 patients (13 females, mean age $59.71 \pm 12.33$ ) underwent their second venography after the follow-up period (mean 4.79 months, range 3 to 6 months) and were included in the analysis. The patients characteristics are summarized in Table 1.

The venography did not show significant venous obstruction in $33(79 \%)$ patients. $9(21 \%)$ patients had more than $50 \%$ obstruction, but none of them had total venous occlusion (Figure 1). Only one of the patients (2\%) presented with mild upper extremity edema, nonetheless all the others were asymptomatic with no abnormalities on physical examination.

We compared patients according to venous patency. The findings are presented in Table 2 . Analysis showed statistically significant differences in the incidence of venous obstruction in terms of number of leads. Patients with obstruction had more leads in their veins $(2.56 \pm 0.53$ vs $1.58 \pm$ $0.71, \mathrm{P}=0.001)$. Venous obstruction was significantly higher in patients with implanted CRT compared to ICD or pacemaker $(\mathrm{P}=0.01)$. Presence of shock lead did not influence on the patency of the veins. Analysis of other factors (including age, gender, and history of diabetes mellitus, hypertension, ischemic heart disease and antiplatelet therapy) failed to reveal any contribution to the risk of thrombosis.

In multivariate logistic regression analysis, we included age, sex, BMI, HTN, and number of leads. This analysis showed that only total lead number was a positive predictor for venous occlusion $(\mathrm{P}=0.015$, OR:19.2, and CI: 1.7-207.1). 
Table 1

Patient characteristics

\begin{tabular}{|c|c|}
\hline $\begin{array}{l}\text { Characteristics } \\
\text { Age (vears) }\end{array}$ & $\mathrm{N}=42$ \\
\hline Age (years) & $59.71 \pm 12.33$ \\
\hline Female & $13(31 \%)$ \\
\hline Diabetes mellitus & $11(26 \%)$ \\
\hline Hypertension & $20(48 \%)$ \\
\hline Ischemic heart disease & $23(55 \%)$ \\
\hline Body mass index $\left[\mathrm{kg} / \mathrm{m}^{2}\right]$ & $25.10 \pm 3.86$ \\
\hline History of antiplatelet therapy & $27(68 \%)$ \\
\hline Smoker & $6(14 \%)$ \\
\hline Left ventricular ejection fraction (\%) & $38.88 \pm 16.90$ \\
\hline \multicolumn{2}{|l|}{ Device type } \\
\hline \begin{tabular}{l|l} 
& Permanent pacemaker \\
\end{tabular} & $15(36 \%)$ \\
\hline Implantable cardioverter-defibrillator & $18(43 \%)$ \\
\hline Cardiac resynchronization therapy & $9(21 \%)$ \\
\hline Total lead number & $1.79 \pm 0.78$ \\
\hline
\end{tabular}

Data are presented as mean $\pm \mathrm{SD}$ or $\mathrm{n}(\%)$

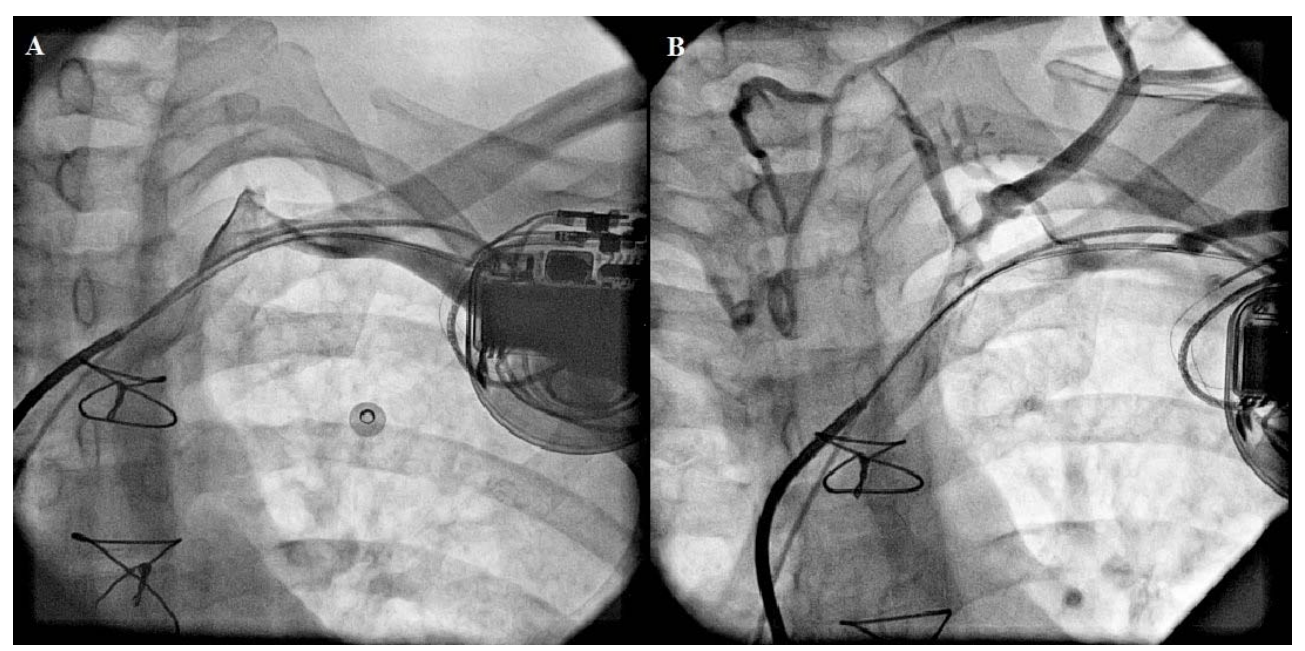

Figure 1. Venography of left subclavian vein in a patient with an implantable cardioverter-defibrillator (A) Patent subclavian vein just after implantation. (B) Significant stenosis of the left subclavian vein with extensive collateral circulation 3 months after implantation.

Table 2

Comparison of risk factors for venous obstruction

\begin{tabular}{|c|c|c|c|}
\hline & $\begin{array}{l}\text { Patients without significant } \\
\text { venous obstruction }(\mathrm{n}=33)\end{array}$ & $\begin{array}{c}\text { Patients with significant } \\
\text { venous obstruction }(n=9)\end{array}$ & $\mathrm{P}$ value \\
\hline Age (years) & $58.97 \pm 12.29$ & $62.44 \pm 12.79$ & 0.46 \\
\hline Female & $9(27 \%)$ & $4(44 \%)$ & 0.42 \\
\hline Left ventricular ejection fraction (\%) & $38.45 \pm 17.22$ & $40.44 \pm 16.56$ & 0.81 \\
\hline Diabetes mellitus & $8(24 \%)$ & $3(33 \%)$ & 0.67 \\
\hline BMI & $25.48 \pm 3.95$ & $23.70 \pm 3.35$ & 0.22 \\
\hline Ischemic heart disease & $19(57 \%)$ & $4(44 \%)$ & 0.71 \\
\hline Hypertension & $17(51 \%)$ & $3(33 \%)$ & 0.46 \\
\hline History of antiplatelet therapy & $22(67 \%)$ & $6(67 \%)$ & 1.0 \\
\hline Device type & & & \multirow[t]{4}{*}{0.01} \\
\hline Pacemaker & $12(80 \%)$ & $3(20 \%)$ & \\
\hline ICD & $17(94 \%)$ & $1(6 \%)$ & \\
\hline CRT-D & $4(44 \%)$ & $5(56 \%)$ & \\
\hline Lead type & & & \multirow[t]{3}{*}{1.0} \\
\hline ICD lead & $21(78)$ & $6(22)$ & \\
\hline Only pacemaker lead & $12(80)$ & $3(20)$ & \\
\hline Total lead number & $1.58 \pm 0.71$ & $2.56 \pm 0.53$ & 0.001 \\
\hline Number of leads & & & \multirow{4}{*}{0.01} \\
\hline 1 & $18(100 \%)$ & $0(0 \%)$ & \\
\hline 2 & $11(73 \%)$ & $4(27 \%)$ & \\
\hline 3 & $4(44 \%)$ & $5(56 \%)$ & \\
\hline
\end{tabular}

Data are presented as mean $\pm \mathrm{SD}$ or $\mathrm{n}(\%)$ 


\section{DISCUSSION}

The present study evaluates the predictors of venous obstruction following transvenous pacemaker or ICD implantation. This study demonstrates that partial venous obstruction is relatively frequent after pacemaker or ICD implantation and is about $21 \%$ in the first 6 months, although there is not any total obstruction. In addition, it shows that pacemaker and ICD leads have a similar risk for leadrelated venous obstruction, and antiplatelet therapy for other reasons does not have any significant preventive effect on the development of the access vein thrombosis, however patients with multiple leads are associated with an increased risk.

Criteria for degree of significant venous stenosis, length of follow-up, imaging modality approach, and portion of each type of cardiac rhythm management device (pacemaker, ICD or CRT) were different in previous reports, thus analysis of these reports is difficult.

In prospective and retrospective studies, assessment of vein patency among patients with endocardial lead was performed by different methods. The incidence of thrombosis was estimated to be about $23 \%$ during the first year of implantation in a study using doppler ultrasound [5]. In studies performing contrast venography, as the gold standard method for detection of venous occlusion, significant abnormal venography results after implantation were detected in 24 to $45 \%$ [4, 9-13]. Most of these previous reports did not investigate the venous system prior to implantation except in one, reported by Oginosawa et al. They showed that incidence of significant venous obstruction was observed in $32.9 \%$ of the patients during 44 months post implantation. However, significant venous obstruction was found in $13.7 \%$ of their patients preimplantation. Therefore, they concluded that the incidence of venous obstruction after pacing lead implantation might be overestimated because of high incidence of venous obstruction before pacing leads implantation [14]. Performing pre-implantation venography, Korkeila et al. showed that the incidence of new venous obstruction was $14 \%$ [15].

Risk factors for venous obstruction after pacemaker implantation are not clearly obvious. There are numerous discrepancies between the results of different studies.

Our study showed that multiple transvenous pacemaker leads increase the risk of venous obstruction and most events were observed in patients with CRT implantation. Number of leads as a risk factor was also detected in some other previous reports $[4,5,16]$. Although some other studies have not approved this correlation. Narrowing of the vessel and endothelial damage due to manipulations with more leads and especially with a guiding catheter during CRT implantation may make the vein susceptible for thrombosis or subsequent scar formation after implanting a CRT. Heart failure and low cardiac output, which reduce the blood flow in the central veins and the increased coagulability state, may also have an additive effect on this susceptibility $[15,17,18]$.

Age, sex, smoking, lead size, and cephalic vs. subclavian approach did not appear to affect the rate of venous obstruction in previous studies [2]. In few reports female hormone use [5], personal history of venous thrombosis [5], left ventricle ejection fraction under $40 \%$ [12], and use of dualcoil ICD leads [6] and infection [19] were associated with higher incidence of obstruction. However, diabetes mellitus [11] and prophylaxis with Warfarin [20] lowered the probability of venous stenosis.

In a case-control venography-based study evaluating the clinical and laboratory risk factors for thrombotic complications (including pulmonary thromboembolism) of pacemaker implantation, no single laboratory or clinical parameter was detected as predictor; however, significant clustering of classic clinical venous thromboembolic risks was seen among the cases [21].

Explaining the discrepancies in reports is very hard and may be due to different study populations and diagnostic methods, as well as various leads dwell time in cardiovascular system.

Our study limitations are the small size of study population and single center experience. Furthermore, evaluation of venous diameter in venography may be affected by degree of venous filling and error in venous diameter measurement, due to poor contrast injection, cannot be excluded.

Nevertheless, most of previous studies on venous occlusion in the presence of endocardial leads were conducted without evaluating venous obstruction prior to implanting the leads. Particularly some reports have shown that the incidence of venous stenosis is not rare before implantation. In this study we performed venography for all patients at the time of implantation and excluded the patients with venous abnormality. 


\section{CONCLUSION}

This study shows that venous obstruction is relatively frequent after pacemaker or ICD implantation even at the first 6 months post implantation. In addition, it demonstrates that patients with multiple leads are associated with an increased risk.

Based on the high prevalence of venous obstruction, venography may be indicated before follow-up procedures such as lead extraction or upgrade, even early post implantation.

Acknowledgments. The authors wish to express their gratitude to Mr Khaligh, Mr Mohtashami, Mr Ferdousi, Mr Fathi, Mr Samadi, Mr Hashemi, Mr Saghzaee, Miss Vatanparast and all the Cath lab technicians of Modarress Hospital performing contrast venography and storage of data.

Conflict of Interest. The authors declare that there are no conflicts of interest.

Introducere. Obstrucția venei de acces după implantarea pacemakerului sau a defibrilatorului este o complicație frecventă. Totuşi incidența acestei complicații precum şi factorii de risc asociați sunt incomplet cunoscuți. Scopul studiului este de a determina incidența şi contribuția fiecărui factor de risc.

Materiale şi metode. 57 de pacienți candidați ce urmau să primească fie pacemaker, terapie de resincronizare cardiacă sau defibrilator implantabil (ICD) au fost înrolați în studiu. După implantare a fost realizată o venografie şi la 3 şi 6 luni pacienții au mai făcut o venografie.

Rezultate. 42 de pacienți au completat studiul (13 femei, media de vârstă a pacienților de $59.71 \pm 12.33)$. Venografiile de urmărire au arătat obstrucție venoasă semnificativă (peste 50\%) la 9 pacienți (21\%). Niciun pacient nu a avut obstrucție completă. Pacienții cu obstrucție venoasă au avut mai multe fire $(2.56 \pm$ 0.53 vs $1.58 \pm 0.71, P=0.001)$. Pacienții cu terapie de resincronizare cardiacă au avut semnificativ mai multe tromboze comparativ cu pacienții cu ICD şi cu pacemaker ( $p=0.01)$. Vârsta, genul, prezența diabetului zaharat, hipertensiunea, boala cardiacă ischemică, terapia antiplachetară nu s-au asociat cu modificarea riscului de tromboză. În modelul de analiză multivariată numărul de fire a fost predictor pozitiv pentru dezvoltarea trombozei $(P=0.015$, OR:19.2, şi CI: 1.7207.1).

Concluzii. Tromboza venoasă post implantare dispozitiv cardiac este relativ frecventă. Pacienții ce au mai multe fire au avut un risc mai mare de a dezvolta tromboză.

Correspondence to: M.A. AKBARZADEH, M.D, Cardiovascular Research Center, Shahid Modarress Hospital, Saadat-Abad Street, Tehran, Iran Tel: (+98)9173171001

E-mail: akbarzadehali@yahoo.com

\section{REFERENCES}

1. SPITTELL PC., HAYES DL. Venous complications after insertion of a transvenous pacemaker. Mayo Clin procs. 1992; 67(3):258-65.

2. ROZMUS G., DAUBERT JP., HUANG DT., ROSERO S., HALL B., FRANCIS C. Venous thrombosis and stenosis after implantation of pacemakers and defibrillators. J Interv Card Electrophysiol. 2005; 13(1):9-19.

3. LI X., ZE F., WANG L., LI D., DUAN J., GUO F., et al. Prevalence of venous occlusion in patients referred for lead extraction: implications for tool selection. Europace. 2014; 16(12):1795-9.

4. HAGHJOO M., NIKOO MH., FAZELIFAR AF., ALIZADEH A., EMKANJOO Z., SADR-AMELI MA. Predictors of venous obstruction following pacemaker or implantable cardioverter-defibrillator implantation: a contrast venographic study on 100 patients admitted for generator change, lead revision, or device upgrade. Europace. 2007; 9(5):328-332. 
5. VAN ROODEN CJ., MOLHOEK SG., ROSENDAAL FR., SCHALIJ MJ., MEINDERS A., HUISMAN MV. Incidence and risk factors of early venous thrombosis associated with permanent pacemaker leads. J Cardiovasc Electrophysiol. 2004; 15(11):1258-62.

6. LICKFETT L., BITZEN A., AREPALLY A., NASIR K., WOLPERT C., JEONG KM., et al. Incidence of venous obstruction following insertion of an implantable cardioverter defibrillator. A study of systematic contrast venography on patients presenting for their first elective ICD generator replacement. Europace. 2004; 6(1):25-31.

7. BAR-COHEN YA., BERUL CL., ALEXANDER ME., FORTESCUE EB., WALSH EP., TRIEDMAN JK., et al. Age, size, and lead factors alone do not predict venous obstruction in children and young adults with transvenous lead systems. J Cardiovasc Electrophysiol. 2006; 17(7):754-9.

8. TRACY CM., EPSTEIN AE., DARBAR D., DIMARCO JP., DUNBAR SB., ESTES NA., et al. 2012 ACCF/AHA/HRS focused update of the 2008 guidelines for device-based therapy of cardiac rhythm abnormalities: a report of the American College of Cardiology Foundation/American Heart Association Task Force on Practice Guidelines. J Am Coll Cardiol. 2012; 60(14):1297-313.

9. ANTONELLI D., TURGEMAN Y., KAVEH Z., ARTOUL S., ROSENFELD T. Short-Term Thrombosis after Transvenous Permanent Pacemaker Insertion. Pacing Clin Electrophysiol. 1989; 12(2):280-2.

10. BULUR S., VURAL A., YAZICI M., ERTAS G., ÖZHAN H., URAL D. Incidence and predictors of subclavian vein obstruction following biventricular device implantation. J Interv Card Electrophysiol. 2010; 29(3):199-202.

11. BOCZAR K.,ZABEK A., HABERKA K., HARDZINA M., DEBSKI M.,RYDLEWSKA A. et al. Venous Stenosis and Occlusion in the Presence of Endocardial Leads. Adv Clin Exp Med. 2016 25(1):83-91.

12. DO CARMO DC., SIDNEY S., NETO AS., COSTA R., CALDAS JG. Incidence and Risk Factors of Upper Extremity Deep Vein Lesions After Permanent Transvenous Pacemaker Implant: A 6-Month Follow-Up Prospective Study. Pacing Clin Electrophysiol. 2002; 25(9):1301-6.

13. AKBARZADEH MA. Venous Obstruction Following Pacemaker or Implantable Cardioverter-Defibrillator Implantation, Mini Review. Int J Cardiovasc Pract. 2016; 1(2):20-2.

14. OGINOSAWA Y., ABE H., NAKASHIMA Y. The incidence and risk factors for venous obstruction after implantation of transvenous pacing leads. Pacing Clin Electrophysiol. 2002; 25(11):1605-11.

15. KORKEILA P., NYMAN K., YLITALO A., KOISTINEN J., KARJALAINEN P., LUND J., et al. Venous obstruction after pacemaker implantation. Pacing Clin Electrophysiol. 2007;30(2):199-206.

16. PAUlETTI M., RICCO G., SOLFANELli S., MARINI C., CONTINI C., GIUNTINI C. Venous obstruction in permanent pacemaker patients: an isotopic study. Pacing Clin Electrophysiol. 1981; 4(1):36-41.

17. MARCUCCI R., GORI A., GIANNOTTI F., BALDI M., VERDIANI V., DEL PACE S., et al. Markers of hypercoagulability and inflammation predict mortality in patients with heart failure. J Thromb Haemost. 2006; 4(5):1017-22.

18. PAULETTI M., PINGITORE R., CONTINI C. Superior vena cava stenosis at site of intersection of two pacing electrodes. Br Heart J. 1979; 42(4):487-9.

19. BRACKE F., MEIJER A., VAN GELDER B. Venous occlusion of the access vein in patients referred for lead extraction. Pacing Clin Electrophysiol. 2003; 26(8):1649-52.

20. COSTA R., DA SILVA KR., RACHED RA., MARTINELLI FILHO MA., CARNEVALE FC., MOREIRA LF. Prevention of Venous Thrombosis by Warfarin after Permanent Transvenous Leads Implantation in High-Risk Patients. Pacing Clin Electrophysiol. 2009; 32(S1):S247-S51.

21. KORKEILA P., MUSTONEN P., KOISTINEN J., NYMAN K., YLITALO A., KARJALAINEN P., et al. Clinical and laboratory risk factors of thrombotic complications after pacemaker implantation: a prospective study. Europace. 2010:12(6):817-24.

Received January 16, 2017 